\title{
Characterization of Ethanol Producing Yeasts for Their Efficiency in Ethanol production, Salt Tolerance, and Utilization of Glucose and Xylose
}

Jarina Joshi

Tribhuvan University

Tribikram Bhattarai

Tribhuvan University

Amar Yadav

Tribhuvan University

Lakshmaiah Sreerama ( $\sim$ Isreerama@gmail.com )

Department of chemistry and earth science, Qatar University, Doha, Qatar https://orcid.org/0000-00029718-5114

Original article

Keywords: yeast, molecular characterization, alcohol dehydrogenase, pyruvate decarboxylase, external voltage

Posted Date: January 24th, 2020

DOl: https://doi.org/10.21203/rs.2.21857/v1

License: (9) This work is licensed under a Creative Commons Attribution 4.0 International License. Read Full License 


\section{Abstract}

Yeasts are the mainstay in ethanol production industry. Search for efficient yeast strains that are salt tolerant and utilize both hexoses (glucose) and pentoses (xylose and arabinose) is important in fermentation industry. In this regard,12 yeast strains, viz., CDBT1-12, were isolated from various sources and characterized. Molecular characterization of the yeast strains was done by sequencing 26S rRNA gene, D1D2 region. Out of 12 isolates, 10 were found to be Saccharomyces cerevisiae, CDBT7 was Wikerhamomyces anomalous, and CDBT8 was Cyberlindnera fabianii . The yeast isolates were characterized in terms of their ethanol production efficiency, salt tolerance and ability to utilize of glucose and xylose. All the strains were found to be good ethanol producers. Yeast strain CDBT2 was found to have tolerance for high salt (up to 15\%) and ethanol (up to 16\%) concentrations. Yeast strain CDBT7 was found to utilize both glucose and xylose without compromising on ethanol production efficiency. The CDBT7 strain was also salt tolerant (up to15\%).Yeast strain CDBT2 when grown in an electrochemical cell with low levels of applied external voltage, alcohol dehydrogenase (ADH1) and pyruvate decarboxylase (PDC1) mRNA levels were increased by $2.78 \pm 0.80$ and $1.12 \pm 0.37$ fold, respectively. We believe, the latter observation is novel and it has not been reported previously. It also further supports our previous observation of increase in level of alcohol production by CDBT2 strain in the presence of applied electrical current.

\section{Introduction}

Yeast strains are the common dwellers of most of nutrient rich media/sources such as fruits, tree bark, soils, etc., [Alfenore et al, 2002]. They form one of the important class of microorganisms that are more complex than bacteria. Unlike other fungi, yeasts are ovoid single cells that are about $8 \mu \mathrm{m}$ long and $5 \mu \mathrm{m}$ in diameter. Their doubling times are 1-3hunder optimal growing conditions [Morris et al, 1992]. According to published news reports the global market for yeast products has reached nearly \$7.6 billion in 2017 and it is increasing rapidly and expected to grow to nearly $\$ 10.7$ billion by 2022 [Globe news wire, 2018]. Yeasts are used for baking, brewing and various other industrial applications. Such applications include manufacturing of shoyu, miso and production of various fermentation products such as enzymes, vitamins, capsular polysaccharides, carotenoids, polyhydric alcohols, lipids, glycolipids, citric acid, etc [Turker, 2014] and as eukaryotic system to produce novel compounds. Given the importance of the yeasts and yeast by products described above, extensive research has been undertaken to identify, catalog and preserve yeast strains worldwide [James et al, 1995].

The process of identification of yeasts involves sequence analysis of ribosomal RNA genes that are conserved. The ribosomal RNA genes coding for both $18 \mathrm{~s}$ and $26 \mathrm{~s}$ RNA have been extensively analyzed and the analysis has proven that it is not only important in establishing them as useful molecular markers for studying evolutionary relationships between organisms but also useful tools for molecular characterization of yeasts [Ciardo et al, 2006]. Early studies related to characterization of yeasts and their classifications have shown a widespread pattern of disparity between phenotypes and genotypes. For the purpose of clarity and to systematically classify yeasts, analysis of genes coding for 18S rRNA [James et 
al, 1995], internal transcribed spacer (ITS) of18s rRNA [Ciardo et al, 2006] and the DNA sequences for domains 1 and 2 (D1/D2) of 26 s rRNA [Kurtzman et al, 2015] have proven to be optimal.

Many efforts have been made to isolate and characterize yeasts from various climates of Nepal with applications in baking and brewing [Karki et al, 2017], however their molecular characterization and systematic evaluation of their application, especially, in brewing is lacking. An important parameter in selecting brewing yeast is its tolerance to salt and ethanol [Kodama et al, 2013], because these are known to damage, the lipid layers and thus destabilize the cultures [Stanley et al, 2013]. Our laboratory has been working towards characterizing various yeast isolates from Nepal, and assesses their ability to tolerate salt and ethanol, and the effect of yeast to electric voltage supply especially on ethanol production [Joshi et al, 2019]. Further, we are also interested in isolating yeasts that utilize both glucose and xylose for alcohol fermentation from xylose containing substrate like lignocellulosic biomass. In the present study, 12 yeast isolates collected from various sources have been characterized by (i) nucleotide sequencing of domains 1 and 2 (D1/D2) of 26 s rRNA genes, (ii) their ability to tolerate salt and ethanol as well as utilization of glucose and xylose as substrates for ethanol production, and (iii) effect of voltage supply on alcohol dehydrogenase and pyruvate decarboxylase expression.

\section{Materials And Methods}

\section{Sample collection}

Samples were collected from different yeast sources available in Kathmandu valley, Nepal as shown in Table 1. All the samples were collected during the months of September and October, and the samples were placed in sterile zip lock bags and stored at $4^{\circ} \mathrm{C}$ until further analysis. 
Table 1

Substrates from which the yeast strains described herein were isolated.

\begin{tabular}{|c|c|c|c|c|}
\hline $\begin{array}{l}\text { S. } \\
\text { No. }\end{array}$ & Sample & Sampling location & Substrate & $\begin{array}{l}\text { Purpose of } \\
\text { use/Source }\end{array}$ \\
\hline 1 & Murcha* & Lubhu, Lalitpur, Nepal & $\begin{array}{l}\text { Steamed } \\
\text { rice }\end{array}$ & Brewing \\
\hline 2 & Manna* & Lubhu, Lalitpur, Nepal & $\begin{array}{l}\text { Steamed } \\
\text { wheat }\end{array}$ & Brewing \\
\hline 3 & Murcha* & Bhaktapur, Nepal & $\begin{array}{l}\text { Steamed } \\
\text { rice }\end{array}$ & Brewing \\
\hline 4 & Manna* & Bhaktapur, Nepal & $\begin{array}{l}\text { Steamed } \\
\text { wheat }\end{array}$ & Brewing \\
\hline 5 & $\begin{array}{l}\text { Freshblack } \\
\text { grape }\end{array}$ & Balkhu, Nepal & Grape pulp & Fruit Pulp \\
\hline 6 & Oak tree bark & $\begin{array}{l}\text { Tribhuvan University premises, } \\
\text { Kirtipur, Nepal }\end{array}$ & Oak bark & Wood source \\
\hline 7 & Guava & $\begin{array}{l}\text { Tribhuvan University premises, } \\
\text { Kirtipur, Nepal }\end{array}$ & Guava fruit & Fruit \\
\hline 8 & Oak Wood & $\begin{array}{l}\text { Tribhuvan University premises, } \\
\text { Kirtipur, Nepal }\end{array}$ & $\begin{array}{l}\text { Oak tree } \\
\text { stem }\end{array}$ & Wood source \\
\hline
\end{tabular}

Isolation of Yeasts

Yeast were isolated from various samples (Table 1) by either taking finger printing in Yeast Maltose agar (YMA) media (Yeast extract: $3 \mathrm{gm} \cdot \mathrm{L}^{-1}$, malt extract: $3 \mathrm{gm} \cdot \mathrm{L}^{-1}$, peptone: $5 \mathrm{gm} \cdot \mathrm{L}^{-1}$, glucose: $10 \mathrm{gm} \cdot \mathrm{L}^{-1}$ agar: $1.5 \mathrm{gm} \cdot \mathrm{L}^{-1}$ and $\mathrm{pH} 4.5$ ) or by overtaxing the sample in Yeast maltose Broth (YMB), followed by serial dilution and spreading them on YMA media. [Karki and Shrestha, 1999; Middlehoven, 2002]. The isolated yeast colonies were sub-cultured and stored in YMA slants and 15\% glycerol.

Biochemical Characterization of Yeast Isolates

Isolated yeasts were studied for their efficiency of budding, utilization of D-glucose and D-xylose, ethanol production from glucose and xylose, ethanol and salt tolerance. Yeasts were allowed to grow in Peptone Yeast extract Nutrient (PYN) media (Peptone: $3.5 \mathrm{gm} \cdot \mathrm{L}^{-1}$, yeast extract: $3 \mathrm{gm} \cdot \mathrm{L}^{-1}, \mathrm{KH}_{2} \mathrm{PO}_{4}: 2 \mathrm{gm} \cdot \mathrm{L}^{-1}$, $\mathrm{MgSO}_{4}: 1 \mathrm{gm} \cdot \mathrm{L}^{-1}$ and $\left.\left(\mathrm{NH}_{4}\right)_{2} \mathrm{SO}_{4}: 1 \mathrm{gm} \cdot \mathrm{L}^{-1}\right)$ and observed microscopically to see budding. PYN media supplemented with $2 \%$ glucose or xylose were used to see the growth and ethanol production efficiency. 
PYN media supplemented with 1-20\% salt (sodium chloride) or ethanol were used for the salt and ethanol tolerance test [Balakumar and Arasaratnam, 2012].

Studies on Glucose and Xylose Utilization and Ethanol Production

All of the isolated yeasts were cultured separately in PYN media supplemented with glucose or xylose as a carbohydrate source. The growth of yeast was observed by measuring absorbance at $600 \mathrm{~nm}$ (turbidity changes) as described by Sherman (2002). Successively, ethanol production was also measured using the protocol of Seo and associates [Seo et al, 2009]. The culture broth was centrifuged at $10000 \mathrm{x} \mathrm{g}$ for $15 \mathrm{~min}$. One $\mathrm{mL}$ of the supernatant was added to $1 \mathrm{~mL}$ tri-n-butyl phosphate (TBP). The mixture was vortexed for $15 \mathrm{~min}$. Finally, the vortexed mixture was centrifuged at $10000 \mathrm{x} \mathrm{g}$ for $15 \mathrm{~min}$ to separate layers. About $750 \mu \mathrm{L}$ of upper layer was transferred to another tube and mixed with equal volume of acidified $5 \%$ potassium dichromate reagent. The process of vortexing and centrifuging was repeated. Then the lower layer was pooled and absorbance was measured at $595 \mathrm{~nm}$ using spectrophotometer. Study of Salt and Ethanol Tolerance by Yeast Isolates

All the isolated yeasts were cultured separately in PYN media supplemented with $0-22 \%$ sodium chloride or ethanol respectively and allowed to grow at $\mathrm{pH} 4.5$ and temperature $28^{\circ} \mathrm{C}$ for $96 \mathrm{~h}$ [Balakumar and Arasaratnam, 2012]. Microbial growth patterns were observed spectrophotometrically for changes in turbidity (Thermo-Scientific, USA) at $600 \mathrm{~nm}$ against medium blank [Sherman, 2002].

\section{Molecular Characterization of Yeasts}

\section{Extraction of DNA from Yeasts}

Total DNA were extracted from broth culture using DNA isolation kit (Promega, Wisconsin, USA). DNA pellet were dried for $15 \mathrm{~min}$ in air and finally re-suspended in $40 \mu \mathrm{L}$ Tris-HCl buffer $(10 \mathrm{mM}, \mathrm{pH}$ 8). The genomic DNA was verified by running DNA in $0.8 \%$ agarose gel electrophoresis. Remaining DNA was stored for PCR analysis.

\section{Amplification of D1D2 Region}

The 26S rRNA gene D1D2 region was amplified by PCR using forward and reverse primers forD1D2 amplification [NL-1 (5'-GCATATCAATAAGCGGAGGAAAAG-3') and NL-4 (5'-GGTCCGTGTTTCAAGACGG-3') respectively]. The expected amplified PCR fragment was $680 \mathrm{bp}$ [Cocolin et al., 2002].PCR was performed in $25 \mu \mathrm{L}$ reaction volume containing: $1 \mu \mathrm{L}(45 \mathrm{ng})$ genomic DNA, $1 \mu \mathrm{L}(25 \mathrm{mM}) \mathrm{MgCl}_{2}, 12.5 \mu \mathrm{L}(2 \mathrm{x})$ master mix, $1.5 \mu \mathrm{L}(10 \mathrm{pM})$ of each primer pair and $7.5 \mu \mathrm{L}$ nuclease free water. Thermo-cycling conditions were $96^{\circ} \mathrm{C}$ for $2 \mathrm{~min}$ for initial denaturation, followed by 35 cycles of $96^{\circ} \mathrm{C}$ for $45 \mathrm{sec}, 52^{\circ} \mathrm{C}$ for $45 \mathrm{sec}, 72^{\circ} \mathrm{C}$ for $2 \mathrm{~min}$. Final elongation was done at $72^{\circ} \mathrm{C}$ for $10 \mathrm{~min}$ and, storage temperature was kept at $4^{\circ} \mathrm{C}$. PCR was performed in Bio-Rad thermos-cycler (Bio-Rad Laboratories, Palo Alto CA, USA).

Aliquots of 5.0 $\mathrm{LL}$ of PCR-amplified products and the 100-bp DNA Ladder (100 to 1500-bp) (Invitrogen Life Technologies, Palo Alto, CA, USA) were loaded onto 1.0\% agarose electrophoresis gels (Sigma Chemical, 
USA). The run was performed with 1x Tris-acetate- EDTA (TAE) buffer, containing $40 \mathrm{mM}$ Tris- $\mathrm{HCl}, \mathrm{pH}$ 8.3, $20 \mathrm{mM}$ acetic acid (Merck, Germany) and $1 \mathrm{mM}$ EDTA (Sigma-Aldrich CO., USA), at $90 \mathrm{~V} \cdot \mathrm{cm}^{-1}$ for $45 \mathrm{~min}$. The gels were stained with ethidium bromide. The stained gels were photographed using UV transilluminator (Eagle Eye II Video Imaging System, Stratagene, San Francisco, Ca, USA).

Phylogenetic Analysis

The PCR products were sequenced at Yeast Genomics Laboratory, Nova University, Lisbon, Portugal and Excelris lab Ahmadabad, India. The sequences obtained were edited, compiled, and aligned using Bio-Edit software. Sequence similarity searches were performed using GenBank Blastn protocol. A phylogenetic tree was generated using the neighbor-joining algorithm in MEGA6 (Molecular Evolutionary Genetics Analysis) software.

\section{Effect of Electric Supply on Expression of Alcohol Dehydrogenase and Pyruvate Decarboxylase}

RT PCR (qPCR) was performed to determine the expression of alcohol dehydrogenase and pyruvate decarboxylase with or without supply of electric field by analyzing the mRNA level. Isolation of RNA from Yeasts

Quick-RNA ${ }^{\text {TM }}$ MiniPrep kit (Zymo Research, Irvine, Ca, USA was used to isolate RNA from yeast isolated. Yeast samples $(200 \mu \mathrm{l})$ were suspended and lysed using $600 \mu \mathrm{l}$ RNA lysis buffer and centrifuged to remove cell debris. The clear supernatant was transferred into spin-away filter fitted with a collection tube, and centrifuged. The filtrate recovered was mixed with equal volume of ethanol (95-100\%) and vortexed. The mixture was then transferred to Zymo-spin IIICG column in a collection tube and centrifuged. The flow through was discarded. The column was first washed with $400 \mu$ I RNA prep buffer and centrifuged, and flow through was discarded. Again washed two times with $700 \mu \mathrm{l}$ and $400 \mu \mathrm{l}$ of RNA wash buffer and centrifuged for 2 min to completely ensure removal of wash buffer. RNA was eluted with $100 \mu$ nuclease free water by centrifugation. The flow through consisted of RNA, which was immediately used to prepare cDNA for further study.

Synthesis of cDNA

Bio-RadiScript ${ }^{\text {TM }}$ cDNA synthesis kit was used for preparation of cDNA. Reaction parameters used for cDNA synthesis was as per the protocol provided by the manufacturer. The total reaction mixture was $20 \mu \mathrm{L}$ and it consisted of $5 \mathrm{x}$ iScript reaction mix $(4 \mu \mathrm{L})$, iScript reverse transcriptase $(1 \mu \mathrm{L})$, nuclease free water $(7 \mu \mathrm{L})$ and RNA template $(8 \mu \mathrm{L})$. The components were mixed by pipetting up and down. PCR cycling conditions were as follows: priming $\left(25^{\circ} \mathrm{C}\right.$ for $\left.5 \mathrm{~min}\right)$, reverse transcription $\left(46^{\circ} \mathrm{C}\right.$ for $\left.20 \mathrm{~min}\right)$, reverse transcription inactivation $\left(95^{\circ} \mathrm{C}\right.$ for $\left.1 \mathrm{~min}\right)$ and holding step $\left(4^{\circ} \mathrm{C}\right)$. The synthesis of cDNA was tested using $0.8 \%$ agarose gel and stored at $-20^{\circ} \mathrm{C}$ for further use.

Quantification of ADH1, PDC1 and TFC1 gene expression 
The levels of expression of ADH1 (Alcohol dehydrogenase 1), PDC1 (Pyruvate decarboxylase 1) with reference to TFC1 (transcription factor 1) genes was quantified by RT PCR [Smidt et al., 2011]. The relative quantification technique was used for the comparison of gene expression relative to the reference gene. TFC1 (a housekeeping gene) was used as the reference gene. Advanced Universal SYBER green supermix dye was used as detector. All the components were thawed to room temperature before use. These reagents and components were centrifuged to collect solutions at bottom of the tube and then stored on ice and protected from light. The reaction mixture contained $15 \mu \mathrm{L}$ with SYBER green super mix $(7.5 \mu \mathrm{L})$, forward primer $(0.35 \mu \mathrm{L})$, reverse primer $(0.35 \mu \mathrm{L})$, nuclease free $\mathrm{H}_{2} \mathrm{O}(5.8 \mu \mathrm{L})$ and cDNA template $(1.0 \mu \mathrm{L})$. All experiments were done in triplicate to optimize the result. Primers used for RT PCR were shown in Table 2.

Table 2

List of primers used in RT PCR

\begin{tabular}{|lll|}
\hline S.N. & Primer Name & Primer Sequence(5'-3') \\
\hline 1. & ALD1F & CGTTTCCGAAGCCGCTATTG \\
\cline { 2 - 3 } & ALD1R & GCATACCGACCAAAACGGTG \\
\hline 2. & PDC1F & GCCAAACGATGCTGAATCCG \\
& PDC1R & CCTTGACGTCGTGTCTGGAA \\
\hline 3. & TFC1F & GCTGGCACTCATATCTTATCGTTTCACAATGG \\
& TFC1R & GAACCTGCTGTCAATACCGCCTGGAG \\
\hline
\end{tabular}

The PCR cycling conditions included denaturation at $95^{\circ} \mathrm{C}$ for 2 min, followed by 34 cycles of denaturation at $95^{\circ} \mathrm{C}$ for $30 \mathrm{sec}$, annealing at $64^{\circ} \mathrm{C}$ for $30 \mathrm{sec}$ and extension at $72^{\circ} \mathrm{C}$ for $30 \mathrm{sec}$. Melting curves were observed and when the PCR run was completed, the data obtained was saved. Further calculation were done manually using the formula listed below [Yuan et al., 2006].

$\Delta \mathrm{Ct}=\mathrm{Ct}($ Test sample) $-\mathrm{Ct}$ (Reference)

$\Delta \Delta \mathrm{C}_{\mathrm{t}}=\mathrm{C}_{\mathrm{t}}$ (Test sample) $-\mathrm{C}_{\mathrm{t}}$ (Control)

\section{Statistical Analysis}

All graphs and statistical calculations were performed using Graph Pad Prism 8.0.1. Values reported herein are mean \pm standard deviation of three independent experiments.

\section{Results}

\section{Isolation of yeasts and molecular characterization}


From the eight different substrates (Table 1) tested, 12 different yeast colonies (CDBT1 to CDBT12) were isolated (Table 3). The isolated yeast were white or creamy colonies with variability in consistency and texture as described by Cletus and associates [Cletus et al., 2011]. All isolates have cottony or rubbery like appearance (Fig. 1, Table 3).

Table 3

Morphological characterization of yeast colonies.

\begin{tabular}{|llll|}
\hline S. No. & Isolate Designation & Colony morphology & Isolate Identified as \\
\hline 1 & CDBT1 & Ovoid, smooth & Saccharomyces cerevisiae \\
\hline 2 & CDBT2 & Ovoid, smooth & S. cerevisiae \\
\hline 3 & CDBT3 & Ovoid smooth & S. cerevisiae \\
\hline 4 & CDBT4 & Ovoid, smooth & S. cerevisiae \\
\hline 5 & CDBT5 & Ovoid, smooth & S. cerevisiae \\
\hline 6 & CDBT6 & Diffused & S. cerevisiae \\
\hline 8 & CDBT7 & Diffused & Wickerhamomyces anomalous \\
\hline 9 & CDBT8 & Ovoid, smooth & Cyberlindnera fabianii \\
\hline 10 & CDBT10 & Diffused & S. cerevisiae \\
\hline 11 & CDBT11 & Ovoid, smooth & S. cerevisiae \\
\hline 12 & CDBT12 & Diffused & S. cerevisiae \\
\hline
\end{tabular}

Biochemical Characterization of Yeast

All the yeast were multiplied by budding and were good ethanol producer (Table 4). CDBT7 and CDBT8, in addition to glucose, were also found to utilize xylose. CDBT2, CDBT3, CDBT7 and CDBT11 were found to tolerate high salt concentrations (15\%). All the yeast strains showed normal growth in the presence of ethanol up to $4 \%$, except CDBT8 that can only tolerate $2 \%$ ethanol (Fig. 2). CDBT2 was found to grow normally in the presence of $6 \%$ ethanol. Almost all yeast strains were found to grow in media with $14 \%$ ethanol, with the exception of CDBT2 in which can resist up to $16 \%$ ethanol in the medium. Overall, from biochemical characterization, CDBT2 and CDBT7 were found to be potent strain for ethanol production as they are high salt and ethanol tolerant, can produce ethanol from glucose and xylose as well. 
Table 4

Study of different features and characters of yeasts: Summary

\begin{tabular}{|lcccccccccccc|}
\hline $\begin{array}{l}\text { Yeast (CDBT)/ } \\
\text { Characters }\end{array}$ & $\mathbf{1}$ & $\mathbf{2}$ & $\mathbf{3}$ & $\mathbf{4}$ & $\mathbf{5}$ & $\mathbf{6}$ & $\mathbf{7}$ & $\mathbf{8}$ & $\mathbf{9}$ & 10 & 11 & 12 \\
\hline Budding & & & & & & & & & & & & \\
\hline Growth/D-Glucose & + & + & + & + & + & + & + & + & + & + & + & + \\
\hline Growth/D-Xylose & + & + & + & + & + & + & + & + & + & + & + & + \\
\hline Ethanol production from glucose & + & + & + & + & + & + & + & + & + & + & + & + \\
\hline Ethanol production from xylose & - & - & - & - & - & - & + & + & - & - & - & - \\
\hline Salt tolerance (\% salt) & - & - & - & - & - & - & + & + & - & - & - & - \\
\hline
\end{tabular}

Molecular Characterization of Yeast: 26S ribosomal D1/D2 segment analysis

The 680 bp amplified 26S rDNA products were confirmed by electrophoresis in 1.0\% agarose gel (Figure.3). The sequences were edited by BioEdit software [Hall, 1999] and analyzed by NCBI blast. Out of twelve yeasts, ten of them were Saccharomyces cerevisiae and CDBT7 and CDBT8 were Wikerhamomyces anomalous and Cyberlindnera fabianii respectively (Table 3). A phylogenetic tree was developed to see the relatedness between the yeasts (Fig. 4) using MEGA6 software. The 26S rDNA fragments of potent yeast strains CDBT2 and CDBT7 were given the gene bank accession numbers MK910215 and MK910216 respectively [Joshi et al., 2019].

\section{Alcohol Dehydrogenase and Pyruvate Decarboxylase Expression Analysis in Normal and Electrochemically Enhanced Fermentation by RT-PCR}

Previously, we have demonstrated enhancement of ethanol production in CDBT2 cultures supplied with low levels of applied electrical current. The rationale for the increased levels of ethanol could be over expression of key alcohol fermentation genes, viz., ADH1 and PDC1. Accordingly, total RNA was isolated from CDBT2 strain cultured under normal conditions and in an electrochemical cell under applied current. The cDNA was prepared from isolated RNA. Both the RNA and cDNA preparations were confirmed by running in $1 \%$ agarose gel (Fig. 5). Real time qPCR was used to quantify the relative expression of genes Pyruvate Decarboxylase (PDC1) and Alcohol Dehydrogenase (ADH1) in normal and electrochemically enhanced yeasts.

Gene expression was analyzed taking same amount of template for both reference/ housekeeping gene TFC1 and test genes PDC1 and ADH1. Relative expression of PDC1 and ADH1 was then calculated comparing the expression of TFC1 gene as reference gene. Gene expression in CDBT2 cultured under 
normal growth conditions was used as control and CDBT2 cultured in an electrochemical cell under applied electricity was used as test sample. The $C_{t}$ data obtained in Table 5 clearly revealed high expression of both the genes than in normal condition. When the obtained $\mathrm{C}_{t}$ data were used to calculate the relative expression of $A D H 1$ and PDC1 genes using the protocol given by Yuan et al. (2006), ADH1 and PDC1 genes were found to express $2.78 \pm 0.80$ and $1.12 \pm 0.37$ fold more than normal fermentation indicating that external voltage supply during growth of yeast enhanced enzyme expression.

Table 5

Average $\mathrm{C}_{t}$ values of ADH1, PDC1 and TFC1 genes obtained from RT PCR.

\begin{tabular}{|lllll|}
\hline S. N. & Culture Types & \multicolumn{2}{l}{$\mathrm{C}_{\mathbf{t}}$ values } & \\
\cline { 3 - 5 } & & ADH1 & PDC1 & TFC1 \\
\hline 1 & CDBT2 (normal growth) & $3.35 \pm 0.51$ & $3.45 \pm 0.10$ & $2.49 \pm 0.21$ \\
\hline 2 & CDBT2 (electrochemically enhanced) & $1.95 \pm 0.26$ & $3.36 \pm 0.01$ & $2.57 \pm 0.29$ \\
\hline Figure 1: & & & \\
\hline
\end{tabular}

\section{Discussion}

Among the 12 yeast isolates, most of the isolated yeast were found to be S. cerevisiae. According to Lene [Lene 2003], several isolates of S. cerevisiae were found to be involved in fermentation. S. cerevisiae shows the polymorphism with some isolates even show phenotypic as well as genotypic characters are different from normally recognized S. cerevisiae strains [Granchi et al., 2019]. Additionally, like CDBT7, W. anomalous strain isolated from sugar beet thick juice was found to have a comparable ethanol yield, but needed longer fermentation time and can utilize xylose [Ruyters et al, 2015]. CDBT2 is found to be potent yeast strain for ethanol production using glucose as substrate. It is also tolerant to high salt and ethanol concentrations. Yeast strain CDBT 7 is also tolerant to high salt and ethanol concentrations; however, it can utilize both glucose and xylose to produce ethanol. Selection of ethanol tolerance strain is must when the yeast is used for industrial production of ethanol [Ekunsanmi and Odunfa, 1990]. Among the various conditions that cause stress to yeast cells during ethanol fermentation, include ethanol toxicity, adverse environmental factors, osmotic shock and salt pressure [Logothetis et al., 2007]. The inability of yeast to adapt to these stressful conditions results in slow or incomplete alcohol fermentation [Zhao and Bai, 2009]. According to Sutticha and associates [Sutticha et al., 2013], ethanol tolerance up to $5 \%$ is considered as good isolate for ethanol production. Most of the isolates of $\mathrm{S}$. cerevisiae reported here in could retain viability up to $46 \%$ in the presence of $5 \%$ ethanol up to $48 \mathrm{~h}$ [Balakumar and Arasaratnam, 2012]. In this regard, CDBT2 can be a good strain for industrial ethanol production as it grows normally up to $6 \%$ ethanol. The other stains described herein show significant decrease in growth after $4 \%$. These results were similar to those reported by Chiranjeevi and associates [Chiranjeevi et al., 2013]. On the other hand, according to Gonzalez and associates [Gonzalez et al., 2002], the ethanol tolerance is found to vary 
slightly with media composition and culture condition. Induced expression of ADH1 and PDC1 in CDBT2 in an electrochemical cell under low applied electrical field is a novel observation and this observation is being further evaluated to enhance ethanol production. TFC1 gene was taken as reference gene to observe induced expression of ADH1 and PDC1 genes. TFC1 is one of the six subunits of RNA polymerase III complex. It is a transcription initiation factor in the RNA polymerase III complex, an essential factor that to regulates expression of housekeeping genes. TFC1 gene is located in chromosome II (484742-486691). PDC1 is the major isozyme among the three pyruvate decarboxylases present in yeast. PDC1 is a key enzyme in alcoholic fermentation that decarboxylates pyruvate to acetaldehyde. PDC1 is also involved in amino acid catabolism. In the yeast genome, PDC1 is located on chromosome XII (232390-234081) [Kellermann et al., 1986]. ADH1 is the main isozyme required for the reduction of acetaldehyde to ethanol in yeast out of four isozymes (ADH 1, 2, 3 and 5).ADH1 gene is located on yeast chromosome XV (159548-160594). ADH5 is a paralog of ADH1, which arose from the whole genome duplication. In the present study, we have observed over expression of both PDC1 and ADH1 mRNA in S. cerevisiae CDBT2 strain cultured in an electrochemical cell under low levels of applied electrical current. Previously we have also reported increased levels of ethanol production by CDBT2 yeast strain under applied electrical field [Joshi et al., 2019]. Induced expression of PDC1 and ADH1 under applied electrical current reported herein is a novel observation. Consistent with this observation is the fact that ADH1 and PDC1 over expression leads to increased production of ethanol in yeast and bacteria [Kata et al, 2016; Tian et al, 2017]. The combination of the two strains can be good candidates for industrial ethanol production from lignocellulosic biomass hydrolysates.

\section{Declarations}

Accession numbers for important species

The accession numbers for important species described herein are (i) Saccharomyces cerevisiae-CDBT2: Gene Bank accession no. MK910215, and (ii) Wickerhamomyces anomalous-CDBT7: Gene Bank accession no MK910216.

Conflict of Interest

There is no conflict of interest for all authors.

Ethics approval and consent to participate

This article does not contain any studies with human participants or animals performed by any of the authors

Consent for publication

Not applicable

Availability of data and material

Page $11 / 17$ 
The dataset and materials supporting the this article is included within the article. All data are fully available without restriction.

\section{Competing interests}

The authors declare that they have no competing interests.

\section{Funding}

Not applicable.

\section{Authors' contributions}

$\mathrm{JJ}, \mathrm{LS}$ and TB conceived and designed experiments. JJ and AY performed the experiments. JJ and LS analyzed the data and wrote the research paper with help from TB and AY. All authors read and approved the final manuscript.

\section{Acknowledgements}

The authors are thank full to Central Department of Biotechnology, Tribhuvan University for providing, laboratory space and instrumental facilities. Our sincere thanks to Dr. Paula Gunclaves, Yeast Genomics Laboratory, Nova University, Lisbon, Portugal for sequencing PCR products and valuable suggestions.

\section{References}

1. Alfenore S, Molina-Jouve C, Guillouet SE, Uribelarrea JL, Goma G, Benbadis L (2002): Improving ethanol production and viability of Saccharomyces cerevisiae by a vitamin feeding strategy during fed-batch process. Appl. Microbiol. Biotechnol. 60:67-72.

2. Balakumar S, Arasaratnam V (2012). Osmo, thermo and ethanol- tolerances of Saccharomyces cerevisiae. J. Microbiol. (1): 157-166.

3. Chiranjeevi T, Osuru H, Navya A, Praveen C, Veera R, Yellapu NK, Ismail S, Mannur U, Venkateswara P, Sudheer A, Narasimha VK Matcha B (2013). Isolation and characterization of ethanol tolerant yeast strains. Bioinformation. 9(8): 421-425.

4. Ciardo DE, Schär G, Böttger EC, Altwegg M, Bosshard PP (2006). Internal Transcribed Spacer Sequencing versus Biochemical Profiling for Identification of Medically Important Yeasts. J. Clin. Microbiol. 44 (1): 77-84.

5. Cletus P, Kurtzman JWF, Teun B, Vincent R (2011). Methods for isolation, phenotypic characterization and maintenance of Yeasts- Chapter 7. The Yeasts, Taxonomic Study. 5: 87-110.

6. Cocolin L, Aggio D, Manzano M, Cantoni C, Comi G (2002). An application of PCR-DGGE analysis to profile the yeast populations in raw milk. Int Dairy J. 12: 407-411. 
7. Ekunsanmi TJ, Odunfa SA (1990). Ethanol tolerance, sugar tolerance and invertase activities of some yeast strains isolated from steep water of fermenting cassava tubers. Journal of Applied Bacteriology. 69: 672-675.

8. GLOBE NEWSWIRE Yeasts, Yeast Extracts, Autolysates and Related Products: The Global Market. Research and Markets. Dublin, Sept. 05, 2017.

9. Gonzalez R, Tao H, Shanmugan KT, York SW, Ingram L O (2002). Global gene expression differences associated with changes in glycolyitc flux and growth rate in Escherichia coliduring the fermentation of glucose and xylose. BiotechnolProg. 18: 6-20.

10. Granchi L, Ganucci D, Buscioni G, Mangani S, Guerrini S (2019). The Biodiversity of Saccharomyces cerevisiae in Spontaneous Wine Fermentation: The Occurrence and Persistence of WineryStrains. Fermentation. 5:

11. Hall TA (1999). BioEdit: A user-friendly biological sequence alignment editor and analysis program for windows 95/98/NT. Nucleic Acids Symp. Ser. 41: 95-98.

12. James CM, Indge KJ, Oliver SG (1995). DNA sequence analysis of a $35 \mathrm{~kb}$ segment from Saccharomyces cerevisiae chromosome VII reveals 19 open reading frames including RAD54, ACE1/CUP2, PMR1, RCK1, AMS1 and CAL1/CDC43. Yeast. 11(14):1413-9

13. Joshi J, Dhungana P, Prajapati B, Maharjan R, Poudyal P, Yadav M, Mainali M, Yadav AP, Bhattarai T, Sreerama L (2019). Enhancement of Ethanol Production in Electrochemical Cell by Saccharomyces cerevisiae (CDBT2) and Wickerhamomyces anomalous (CDBT7). Frontiers in Energy Research. 7: 10 pgs

14. Karki TB, Timilsina PM, Yadav A (2017). Selection and Characterization of Potential Baker's Yeast from Indigenous Resources of Nepal. Biotechnology Research International. 2017, Article ID 1925820, 10 pages.

15. Karki T, Shrestha H (1999). Fermentation process of Nepal murcha starters. Proceedings of III National Conference on Science and Technology. 380-388.

16. Kata I, Marta VS, Justyna R, Kostyantyn VD, Andriy AS (2016). Overexpression of the genes PDC1 and $\mathrm{ADH} 1$ activates glycerol conversion to ethanol in the thermotolerant yeast Ogataea (Hansenula polymorpha). Yeast.33(8): 471-478.

17. Kodama S, Nakanishi H, Thalagala TA, Isono N, Hisamatsu M (2013). A wild and tolerant yeast suitable for ethanol fermentation from lignocellulose. J BiosciBioeng. 115(5):557-61

18. Kurtzman C, Raquel P, Quintilla M, Anna K, Bart T, Vincent R, Teun B (2015). Advances in yeast systematics and phylogeny and their use as predictors of biotechnologically important metabolic pathways. FEMS Yeast Research.15(6).

19. Lene J (2003). Occurrence and taxonomic characteristics of strains of Saccharomyces cerevisiaepredominant in African indigenous fermented foods and beverages, FEMS Yeast Research. 
3(2): 191-200.

20. Livak KJ, Schmittgen TD (2001). Analysis of relative gene expression data using real-time quantitative PCR and the 2(-Delta DeltaC(T)) method. Methods. 25(4):402-8.

21. Logothetis S, Walker G, Nerantzis E (2007). Effect of salt hyperosmotic stress on yeast cell viability. Proc Nat SciMaticaSrpska Novi Sad. 113: 271-284.

22. Middlehoven WJ (2002). Identification of yeast present in sour fermented foods and fodders. Molbiotechnol. 21(3): 279-292.

23. Morris W, Shu C Kim, D.(1992).Bioconversion of waste paper to ethanol. Process Biochemistry. 27( 4): 239-245.

24. Ruyters S, Mukherjee V, Verstrepen KJ, M, Lievens B (2015). Assessing the potential of wild yeasts for bioethanol production. J IndMicrobiolBiotechnol.42(1):39-48.

25. Seo HV, Kim H, Kim O, Lee, Lee H, Jung K (2009). Measurement of ethanol concentration using solvent extraction and dichromate oxidation and its application to bioethanol production process. $\mathrm{J}$ Ind Microbiol Biotechnol. 36:285-92.

26. Sherman F (2002). Getting Started with Yeast. Methods in Enzymology. 350: 3-41.

27. Smidt OD, James C, Preez D, Albertyn J (2011). Molecular and physiological aspects of alcohol dehydrogenases in the ethanol metabolism of Saccharomyces cerevisiae. FEMS Yeast Research. 12: 33-47.

28. Stanley D, Fraser S, Stanley GA, Chambers PJ (2010). Retrotransposon expression in ethanolstressed Saccharomyces cerevisiae. Appl. Microbiol. Biotechnol. 87(4):1447-54.

29. Sutticha N, Thammasittirong T, Thammasittirong T, Malee S (2013). Improvement of ethanol production by ethanol-tolerant Saccharomyces cerevisiae Springerplus. 2: 583.

30. Tian L, Perot SJ, Hon S, Zhou J, Liang X, Bouvier JT, Lynd LR (2017). Enhanced ethanol formation by Clostridium thermocellum via pyruvate decarboxylase. Microbial cell factories. 16(1), 171.

31. Türker M (2014). Advances in Science and Industrial Productions of Baker's Yeast. Conference: Yeast Biotechnology: Diversity and Applications..,Proceedings of 27th VH Yeast Conference, April 14th 15th, 2014, Istanbul.

32. Yuan J, Reed A, Chen F, Neal SC (2006). Statistical analysis of real-time RT-PCR data. BMC bioinformatics. 7: 85-97.

33. Zhao XQ, and Bai FW (2009). Mechanisms of yeast stress tolerance and its manipulation for efficient fuel ethanol production. Journal of Biotechnology. 144: 23-30.

\section{Figures}



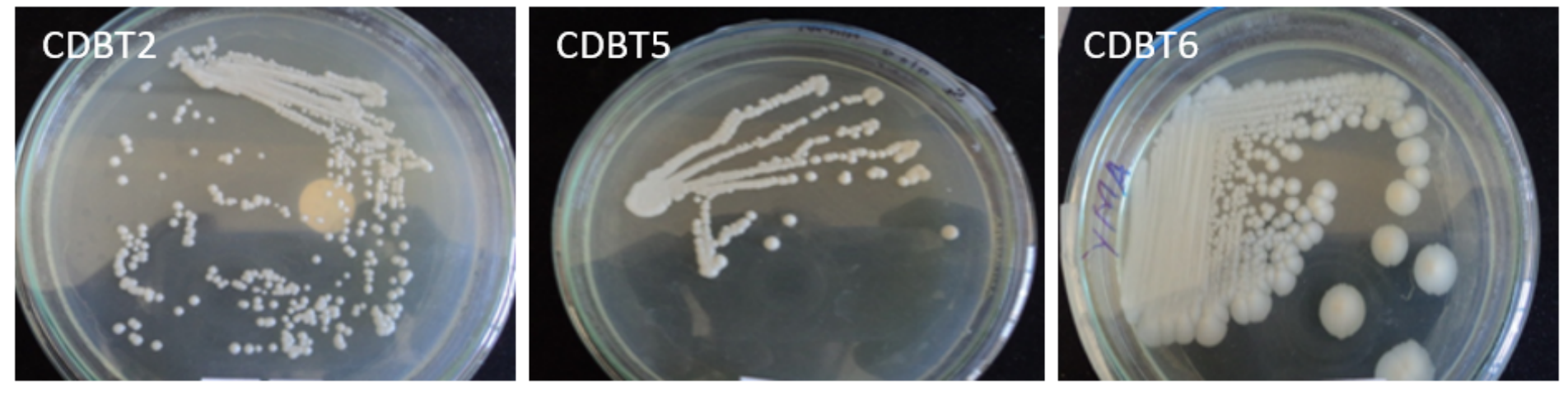

Figure 1

Yeast isolates grown onYMA media - colony morphologies of representative yeast isolates.

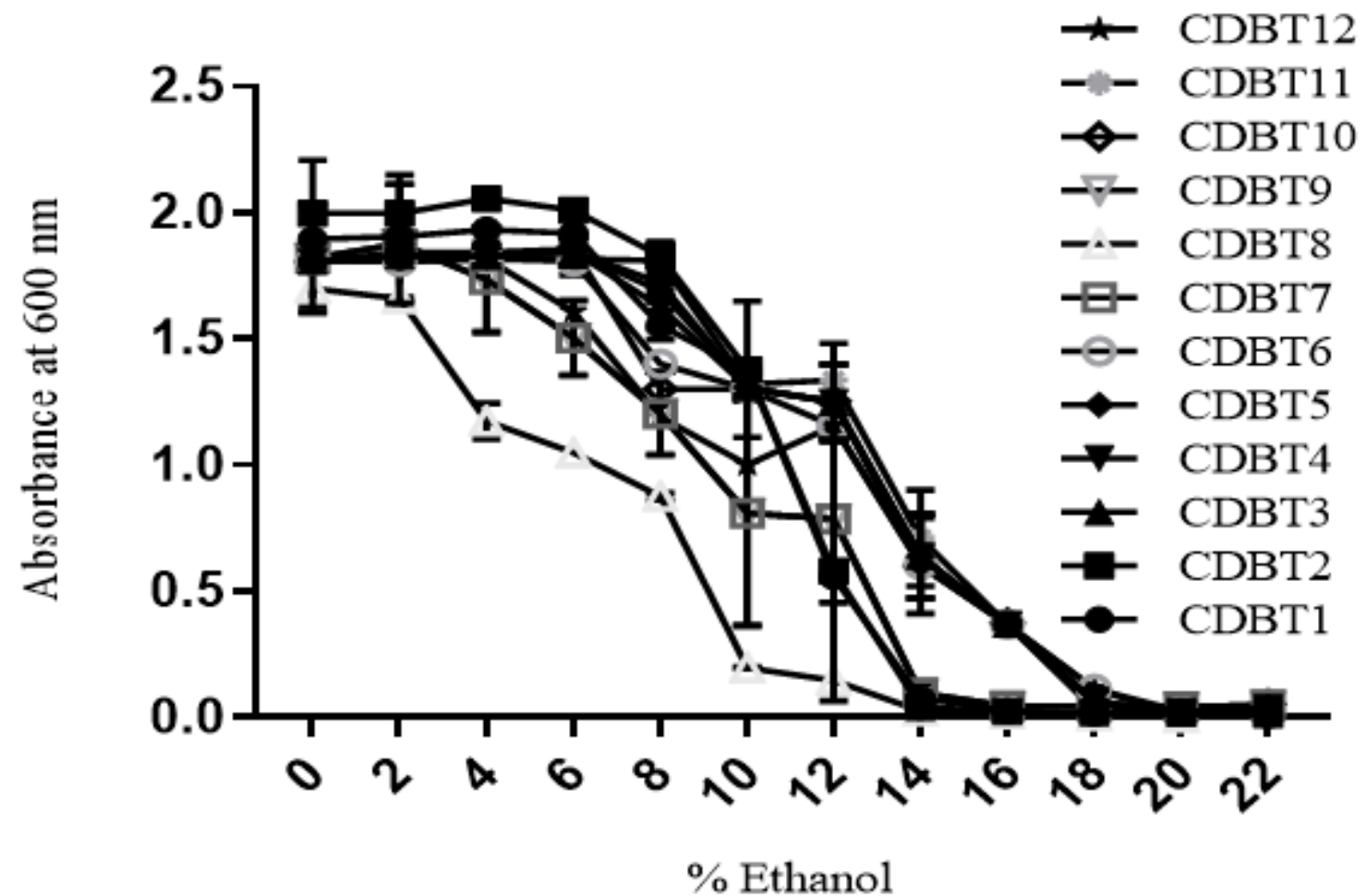

Figure 2

Effect of ethanol concentration on yeast growth. Ethanol concentrations tested ranged of $0-22 \%$. 


\section{L1 L2 : L3 L4}

\section{Figure 3}

Amplification of $680 \mathrm{bp}$ fragment of D1D2 of 26S rDNA from yeast isolates.L1: CDBT1, L2:CDBT2, L3:CDBT3 and L4:CDBT4.

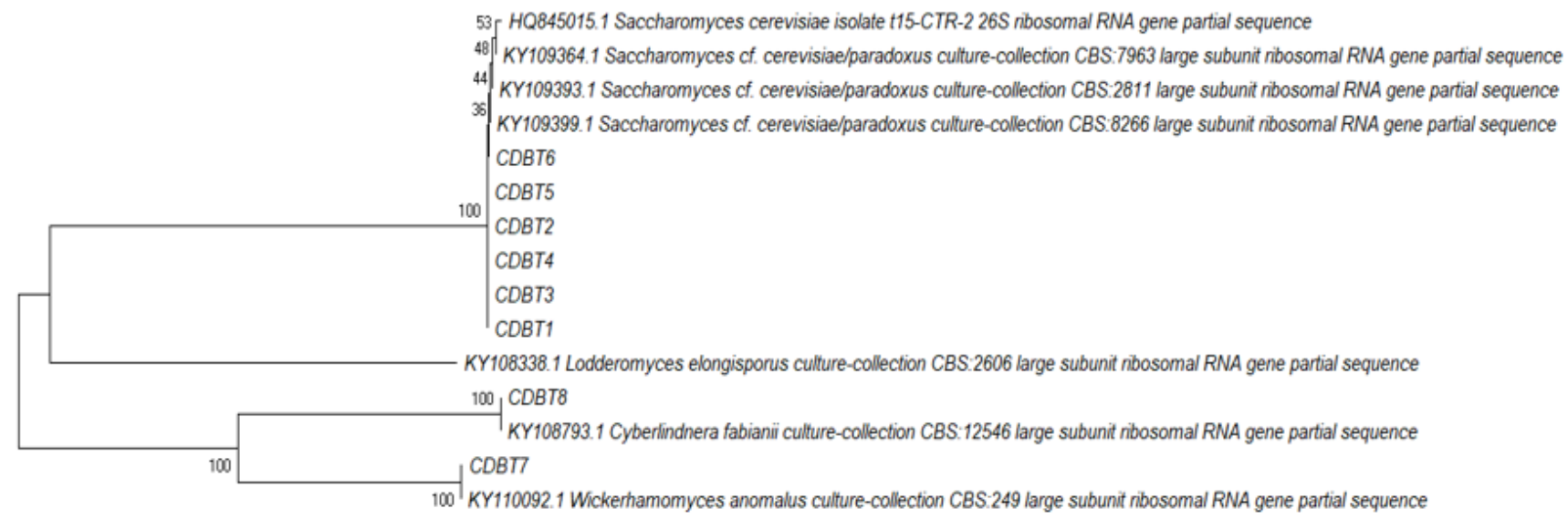

0.020

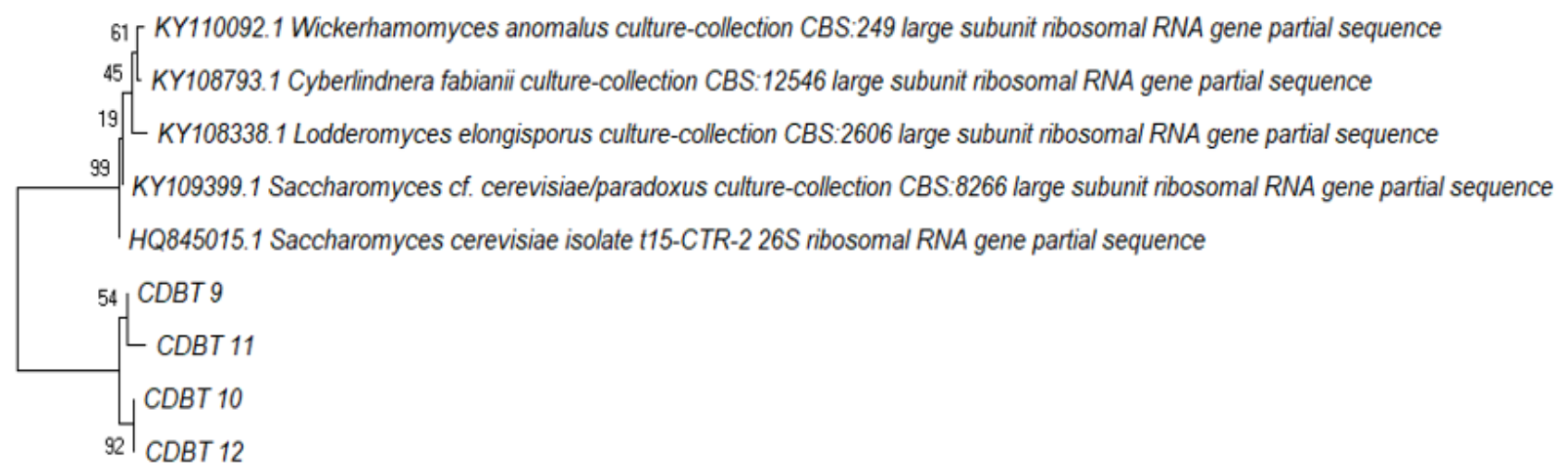

\section{Figure 4}


Phylogenetic tree based on sequences of the D1/D2 region of the rDNA 26S gene. The tree shows the position of CDBT isolates to be closely related yeast species. The tree was constructed based on the genetic distances obtained according to MEGA6 using the neighbor-joining method.

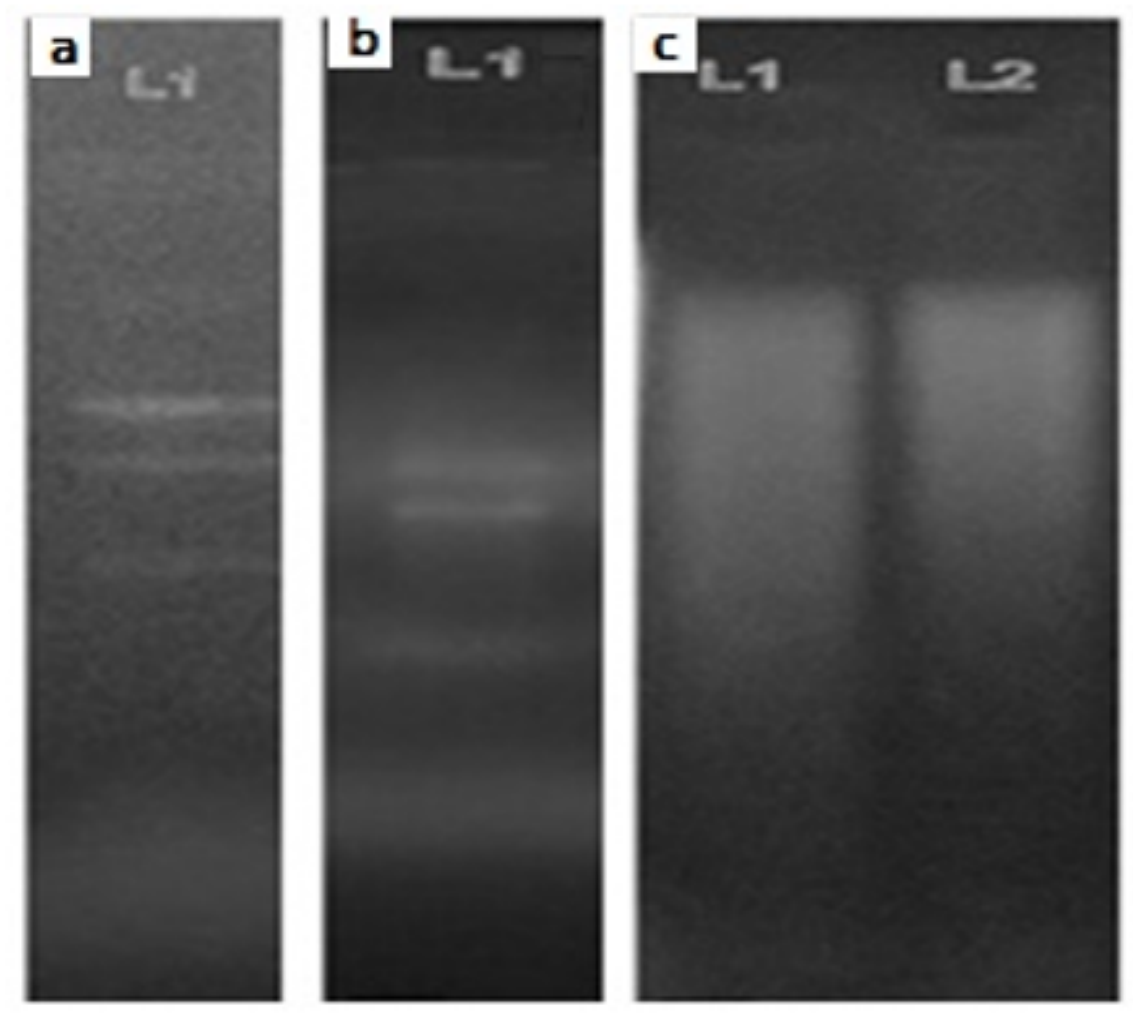

\section{Figure 5}

RNA analysis in yeast strains and cDNA preparation. Panel a: RNA isolated from yeast culture (normal growth). Panel b: RNA isolated from yeast culture (electrochemically enhanced). Panel c: cDNA prepared after RNA isolation and confirmative analysis of the transcribed RNA on 1\% agarose gels. 